\title{
Meta-constraints: Constraint Interaction and Gender Assignment in Ukrainian"
}

\author{
TORE NESSET \\ University of Tromsø
}

\section{Introduction}

Gender (agreement class) represents a perfect testing ground for hypotheses about constraint interaction in that conflicts between constraints assigning different genders often arise. In this paper I present an Optimality Theory (OT) analysis of gender assignment in Ukrainian. The contribution of the paper is twofold. First, I show that nine ranked constraints suffice to account for the assignment of gender to the vast majority of Ukrainian nouns. Secondly, it is argued that the constraint rankings in part fall out as automatic consequences of universal constraints on constraint interaction - what I refer to as "meta-constraints". In addition to the widely accepted Panini's Theorem, I shall propose a meta-constraint that I call the Core Semantic Override Principle.

The meta-constraint approach explored in this paper bears on a current debate in OT. While ranking of constraints is essential in OT, some researchers have noted that phonological systems display less variation than free ranking would give us (cf. Steriade 2001, de Lacy 2003). My analysis suggests that this does not only apply to phonology, and that overgeneration can be restricted in principled ways by means of meta-constraints.

After a thorough discussion of the relationship between declension and gender in section 1, semantic constraints are investigated in section 2. Section 3 explores constraint interaction and meta-constraints, before the contribution of the paper is summarized in section 4 .

\section{Morphological Constraints}

For the purposes of this paper I adopt Hockett's (1958:231) well-known definition: "Genders are classes of nouns reflected in the behavior of associated words".

\footnotetext{
* I would like to thank Henning Andersen, Hans-Olav Enger, Bruce Morén, Curt Rice and audiences at BLS, University of Tromsø and University of North Carolina at Chapel Hill for valuable comments on earlier versions of this paper. Thanks also to Tamara Lönngren for sharing her knowledge of the Ukrainian language with me. All errors are mine.
} 


\section{Meta-Constraints}

Ukrainian has three genders, masculine, feminine and neuter, as witnessed by the sentences in (1), where the nouns take different agreement targets. ${ }^{1}$
a. $\mathrm{Na}$ stoli ležav
smačnyj
xlib.
on table lay.MASC.SG
tasty.MASC.SG
bread
'On the table there was tasty bread.'
b. Na stoli ležala smačna perepička.
on table lay.FEM.SG tasty.FEM.SG Ukrainian pastry
'On the table there was tasty Ukrainian pastry.'
c. Na stoli ležalo kopčene salo.
on table lay.NEUT.SG smoked.NEUT.SG bacon
'On the table there was smoked bacon.'

In Ukrainian, there is a close relationship between a noun's gender and its inflection class (declension). I propose six declensions instead of the more traditional analysis with four declensions (cf. e.g. Bilodid 1969 and Hryščenko 1997). Since my analysis is somewhat untraditional, it is useful to start with an explicit definition of inflection class:

Inflection class:

[A] class of lexemes which share:

- a paradigm consisting of a set of "cells", i.e. inflectionally realised morphosyntactic properties or combinations of properties [...],

- all the inflectional markers, or exponents, which realise these cells [...] (Carstairs-McCarthy 2000:630).

On the basis of the definition in (2), I shall say that two nouns belong to the same declension if they have the same inflectional endings in the relevant paradigm cells. If not, they belong to different declensions. However, as pointed out by Carstairs-McCarthy (2000:632), there is one systematic exception. Even if two nouns combine with different endings, it is customary to relegate them to the same declension if the choice between the endings is predictable on independent grounds. This practice will be adopted here. Thus, zemlja 'earth, land' and voda 'water' belong to the same declension although the former takes the ending - eju in the instrumental singular, while the latter has -oju in this cell of the paradigm. The reason is that the choice of ending is predictable on the basis of the quality of the stem-final consonant. After a palatalized ("soft") consonant $-e j u$ is selected, while -oju occurs after non-palatalized ("hard") consonants.

With the definition in (2) in mind, consider now the list of endings given in (3). The table contains the endings in the singular only, since this is sufficient to establish the number of declensions that are relevant for gender assignment. In

\footnotetext{
${ }^{1}$ The sentences in (1) were produced by a native speaker of Ukrainian. Throughout the paper, examples are given in transliterated orthography.
} 


\section{Tore Nesset}

order to avoid unnecessary complications, endings combining with stems in palatalized consonants have been omitted in cells with alternations of the -eju/-oju type treated above. All endings are given in phonemic transcription. The choice between the alternative endings in column 1 is partly predictable (see e.g. Pugh and Press 1999:70f. and Shevelov 1993:958 for overviews). The endings given in column 5 are those of nouns with (oblique) stems in $/ \mathrm{t} /$, e.g. telja 'calf' (cf. genitive singular teljat-y). Nouns with (oblique) stems in /n/ (e.g. im 'ja 'name', cf. genitive singular imen-i) are inflected somewhat differently. However, since the choice of endings is predictable from the quality of the stem-final consonant, the differences do not form the basis for establishing two declensions. I have only included the endings of the $/ \mathrm{t} /$-stems in the table, since these nouns constitute the larger set and even evince some productivity (Shevelov 1993:959). Column 6 comprises so-called indeclinable nouns, i.e. nouns that combine with a zero ending throughout the paradigm. While these nouns are traditionally treated as standing outside the declension system, Corbett and Fraser (2000a:308), observe that the fact that nouns of this type do not combine with other endings than the zero ending is itself a fact about their inflectional behavior. Therefore, including them in the table seems justified.

Ukrainian noun inflection: endings in the singular

\begin{tabular}{|l|llllll|}
\hline & 1 & 2 & 3 & 4 & 5 & 6 \\
\hline Nominative & $-\varnothing,-\mathrm{o}$ & $-\mathrm{a}$ & $-\varnothing$ & $-\mathrm{o}$ & $-\mathrm{a}$ & $-\varnothing$ \\
Accusative & $-\varnothing,-\mathrm{a}$ & $-\mathrm{u}$ & $-\varnothing$ & $-\mathrm{o}$ & $-\mathrm{a}$ & $-\varnothing$ \\
Genitive & $-\mathrm{a},-\mathrm{u}$ & $-\mathrm{y}$ & $-\mathrm{i}$ & $-\mathrm{a}$ & $-\mathrm{y}$ & $-\varnothing$ \\
Dative & $-\mathrm{u},-\mathrm{ov}$ 'i & $-\mathrm{i}$ & $-\mathrm{i}$ & $-\mathrm{u}$ & $-\mathrm{i}$ & $-\varnothing$ \\
Instrumental & $-\mathrm{om}$ & $-\mathrm{oju}$ & $-\mathrm{ju}$ & $-\mathrm{om}$ & $-\mathrm{am}$ & $-\varnothing$ \\
Locative & $-\mathrm{i},-\mathrm{u},-\mathrm{ov}$ 'i & $-\mathrm{i}$ & $-\mathrm{i}$ & $-\mathrm{i}$ & $-\mathrm{i}$ & $-\varnothing$ \\
Vocative & $-\mathrm{e},-\mathrm{u}$ & $-\mathrm{o}$ & $-\mathrm{e}$ & $-\mathrm{o}$ & $-\mathrm{a}$ & $-\varnothing$ \\
\hline Examples & stil & noga & sil' & slovo & telja & pjure \\
& 'table' & 'leg' & 'salt' & 'word' & 'calf' & 'purée' \\
\hline
\end{tabular}

How many declensions can be established on the basis of the table in (3)? Many cases involve considerable syncretism. For instance, in the locative, the ending $-i$ is found in five of the six columns. Nevertheless, each column represents a declension. Consider first the instrumental, where we have five different endings. This enables us to establish five declensions. What remains to be shown is whether columns 1 and 4 represent different declensions even though they display the same ending in the instrumental case (and some other cases). At least two arguments suggest that we are dealing with two different declensions. First, columns 1 and 4 involve different endings in the accusative and the vocative. Secondly, while column 1 involves two or three endings in several cases, no such variation is found in column 4 . Since the two columns contain different sets of endings, the definition in (2) enables us to establish a total of six declensions for Ukrainian. 


\section{Meta-Constraints}

Against this line of reasoning one might object that some of the differences are predictable on independent grounds if gender is taken into consideration (cf. Andersen 1994 for an analysis along these lines). For instance, nouns with the endings in column 4 are neuter, while nouns with endings from column 1 belong to the masculine gender. Hence, it might be argued, the two columns represent one declension since the differences are predictable from gender. However, Corbett (1982, see also Corbett 1991 and Corbett and Fraser 2000a) has shown that an approach where declension is predicted on the basis of gender is problematic for Russian, and his argument seems to hold for Ukrainian as well. Consider the relationship between declension and gender, which is spelt out below. $^{2}$

The declension-gender interface

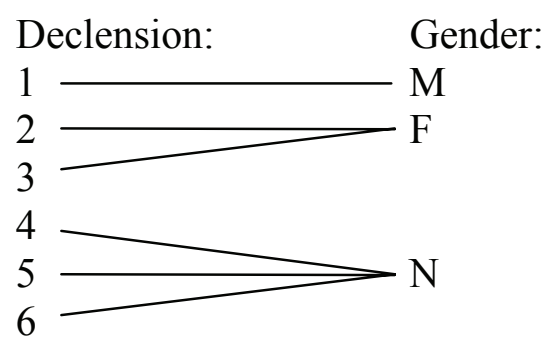

As can be seen from the figure, gender is predictable from declension since a unique path takes us from each declension to one and only one gender. However, if we take gender to be the basis for predicting declension, we get into trouble. For instance, feminine gender is compatible with classes 2 and 3, so if the lexical representation of a noun includes reference to feminine gender, there is no way to infer from this how the noun is inflected. In order to save the gender-todeclension approach, one would have to rely on extensive lexical marking of declension. For instance, one might have to mark all the nouns of class 3 as lexical exceptions. The declension-to-gender approach, on the other hand, does not lead to such problems. In the following discussion, therefore, I shall adopt the latter approach. I shall not conflate any classes even if the differences between them are predictable from gender. Accordingly, I shall assume each of the six columns in the table in (3) to be separate declensions.

On the basis of the figure in (4), I propose the following gender assignment constraints:

\footnotetext{
${ }^{2}$ The figure is somewhat simplified insofar as there are some masculine nouns in declension 2 (e.g. djadja 'uncle') and several non-neuters in declension 6 (e.g. the masculine proteže 'protégé' and the feminine ledi 'lady'). As will become clear in section 2 below, these nouns will be accounted for by means of semantic constraints, which I assume take precedence over the relevant morphological constraints. The nouns in question are therefore not relevant for the present discussion of morphological assignment constraints.
} 


\section{Tore Nesset}

(5) Morphological constraints (declension to gender)
a. Declension $2 \rightarrow \mathrm{F}$
b. Declension $3 \rightarrow \mathrm{F}$
c. Declension $4 \rightarrow \mathrm{N}$
d. Declension $5 \rightarrow \mathrm{N}$
e. Declension $6 \rightarrow \mathrm{N}$

The constraints are labeled according to the nature of the information to the left of the arrows. Since the declensions are aspects of the morphology of the relevant lexemes, the constraints in (5) are referred to as "morphological". The information to the right of the arrows represents the genders, which I abbreviate as $\mathrm{M}$ (masculine), $\mathrm{F}$ (feminine) and $\mathrm{N}$ (neuter). The arrows stand for implicational relationships between two pieces of information, in this case declension and gender. Notice that the arrows do not represent procedural rewrite rules.

Under (5) I have not included a constraint for the masculine gender. As can be seen from (4), however, there is a one-to-one relationship between declension 1 and the masculine gender. Accordingly, it is possible to state a constraint capturing a bi-implicational relation between declension 1 and the masculine gender. However, while such a constraint may be realistic in that speakers in this case may establish the gender from the declension and vice versa, this constraint is superfluous in the formal analysis of gender assignment in Ukrainian. On the basis of numerical preponderance and the assimilation of borrowings, Corbett and Fraser (2000b:68) argue that masculine is the default gender for nouns in Russian (and declension 1 the default declension class). Their arguments seem to carry over to Ukrainian as well, and I therefore propose the constraint in (6) assigning masculine gender by default. The suspension points to the left of the arrow indicate that no particular information is required in order to motivate the selection of the masculine. This gender is assigned to all the nouns to which other constraints do not apply:

$$
\begin{array}{lll}
\text { Default constraint } \\
\ldots & \rightarrow & \mathrm{M}
\end{array}
$$

\section{Semantic Constraints}

While the constraints proposed in section 1 suffice to predict the correct gender of the majority of Ukrainian nouns, additional constraints are required in some cases. Ukrainian nouns denoting male persons or animals belong to the masculine gender, while nouns denoting female persons or animals are feminine. Thus syn 'son', djadja 'uncle' and žerebec' 'stallion' are masculine, while dočka 'daughter', titka 'aunt' and kobyla 'mare' are feminine:

(7) Semantic constraints (biological sex to gender)
a. Biological male $\rightarrow \mathrm{M}$
b. Biological female $\rightarrow \quad F$ 


\section{Meta-Constraints}

Very often, these constraints predict the same gender as the constraints introduced in the previous section. For instance, docka 'daughter', titka 'aunt' and kobyla 'mare' belong to declension 2, and would therefore be feminine according to (5a), while syn 'son' and žerebec' 'stallion' belong to declension 1, and would be masculine according to the default constraint in (6). Nevertheless the semantic constraint in (7a) cannot be dispensed with, as demonstrated by a group of second declension nouns denoting male persons, e.g. djadja 'uncle'. While constraint (5a) suggests feminine gender, nouns of this type are consistently masculine in Ukrainian. A similar assignment conflict arises for declension 6 nouns (indeclinable nouns) denoting females, e.g. ledi 'lady' and names like Esfir (Pugh and Press 1999:51). Nouns of this type are feminine as predicted by (7b), not neuter as (5e) would suggest. If we assume the semantic constraints in (7) to outrank the competing constraints proposed in the previous section, we are in a position to assign the right gender to nouns denoting persons or animals of a particular biological sex. This is illustrated by the tableaux in (8) and (9). (For simplicity, irrelevant constraints are omitted.)

Assignment of masculine gender to djadja 'uncle'

\begin{tabular}{|c||c|c|}
\hline & $\begin{array}{c}(7 \mathrm{a}) \\
\text { Male } \rightarrow \mathrm{M}\end{array}$ & $\begin{array}{c}(5 \mathrm{a}) \\
\text { Decl } 2 \rightarrow \mathrm{F}\end{array}$ \\
\hline \hline a. djadja & & $*$ \\
\hline b. djadja & & \\
\hline c. djadja & $* !$ & $*$ \\
\hline
\end{tabular}

Assignment of feminine gender to ledi 'lady'

\begin{tabular}{|c||c|c|}
\hline & $\begin{array}{c}(7 \mathrm{~b}) \\
\text { Female } \rightarrow \mathrm{F}\end{array}$ & $\begin{array}{c}(5 \mathrm{e}) \\
\text { Decl } 6 \rightarrow \mathrm{N}\end{array}$ \\
\hline \hline a. ledi $i_{\mathrm{M}}$ & $* !$ & $*$ \\
\hline b. ledi $i_{\mathrm{F}}$ & & $*$ \\
\hline c. ledi $i_{\mathrm{N}}$ & $* !$ & \\
\hline
\end{tabular}

Animacy plays an important part in the gender systems of many languages (Corbett 1991, Dahl 2000), and Ukrainian is no exception in this respect. While constraint (5e) predicts neuter gender for declension 6 nouns, animate nouns in this declension tends to be masculine unless they refer to females, in which case they are feminine (cf. Pugh and Press 1999:56ff.). Examples include the masculine words kakadu 'cockatoo', parvenju 'parvenue', flaminho 'flamingo' and proteže 'protégé', and feminines like ledi 'lady'. While the possibility of feminine agreement for females can be accounted for in terms of the sex-based constraint (7b) as shown in (9), we need a constraint assigning masculine gender to animate nouns:

(10) Semantic constraint (animacy to gender)

Animate $\rightarrow \quad \mathrm{M}$ 


\section{Tore Nesset}

It is important to notice that (10) only applies to nouns in declension 6; other animate nouns receive gender according to their declension class. Thus, nouns like antylopa 'antelope', zebra 'zebra', mavpa 'monkey', ryba 'fish' and persona 'person' are feminine because they belong to declension 2. ${ }^{3}$ Likewise, declension 3 nouns like rys' 'lynx' and postat' 'figure' are feminine, while declension 4 nouns like stvorinnja 'creature' and declension 5 nouns like telja 'calf' are neuter. We can account for this if we assume that the animacy constraint (10) is ranked above (5e), but below the remaining morphological constraints in (5). An alternative approach will be discussed in section 3 below. The proposed analysis is illustrated in the following tableaux:

Assignment of masculine gender to kakadu 'cockatoo'

\begin{tabular}{|c|c|c|c|}
\hline & $\begin{array}{c}(5 \mathrm{a}) \\
\text { Decl 2 } \rightarrow \mathrm{F}\end{array}$ & $\begin{array}{c}(10) \\
\text { Animate } \rightarrow \mathrm{M}\end{array}$ & $\begin{array}{c}(5 \mathrm{e}) \\
\text { Decl 6 } \rightarrow \mathrm{N}\end{array}$ \\
\hline \hline a. $k a k a d u_{\mathrm{M}}$ & & & $*$ \\
\hline b. $k a k a d u_{\mathrm{F}}$ & & $* !$ & $*$ \\
\hline c. $k a k a d u_{\mathrm{N}}$ & & $* !$ & \\
\hline
\end{tabular}

(12) Assignment of feminine gender to zebra 'zebra'

\begin{tabular}{|c||c|c|c|}
\hline & $\begin{array}{c}(5 \mathrm{a}) \\
\text { Decl } 2 \rightarrow \mathrm{F}\end{array}$ & $\begin{array}{c}(10) \\
\text { Animate } \rightarrow \mathrm{M}\end{array}$ & $\begin{array}{c}(5 \mathrm{e}) \\
\operatorname{Decl} 6 \rightarrow \mathrm{N}\end{array}$ \\
\hline \hline a. $z e b r a_{\mathrm{M}}$ & $* !$ & & $*$ \\
\hline b. $z e b r a_{\mathrm{F}}$ & & $*$ & $*$ \\
\hline c. $z e b r a_{\mathrm{N}}$ & $* !$ & $*$ & \\
\hline
\end{tabular}

The animacy constraint is also ranked below the competing (7b) assigning feminine gender to biological females, since e.g. ledi 'lady' is feminine:

Assignment of feminine gender to ledi 'lady' (second version)

\begin{tabular}{|c||c|c|c|}
\hline & $\begin{array}{c}(7 \mathrm{~b}) \\
\text { Female } \rightarrow \mathrm{F}\end{array}$ & $\begin{array}{c}(10) \\
\text { Animate } \rightarrow \mathrm{M}\end{array}$ & $\begin{array}{c}(5 \mathrm{e}) \\
\text { Decl } 6 \rightarrow \mathrm{N}\end{array}$ \\
\hline \hline a. ledi $i_{\mathrm{M}}$ & $* !$ & & $*$ \\
\hline b. ledi $i_{\mathrm{F}}$ & & $*$ & $*$ \\
\hline c. ledi $i_{\mathrm{N}}$ & $* !$ & $*$ & \\
\hline
\end{tabular}

The list of obligatory or optional semantic constraints may certainly be extended. For instance, indeclinable nouns denoting languages, e.g. urdu 'Urdu', hindi 'Hindi' and esperanto 'Esperanto', are reported to be compatible with femi-

\footnotetext{
${ }^{3}$ An interesting exception is suddja 'judge', which is reported to be masculine although it belongs to declension 2 and may refer to both male and female persons (cf. Bilodid (ed.) 1970-80; for discussion of the Russian cognate sudja, see Dahl 2000:108ff.). A conceivable analysis would involve an additional semantic constraint assigning masculine gender to nouns denoting certain professions that have traditionally been dominated by men.
} 


\section{Meta-Constraints}

nine agreement (Pugh and Press 1999:57). It is possible to account for facts like these if we assume that an additional semantic constraint for these nouns outranks the morphological (5e) in the same way as the animacy constraint in (10) takes precedence over (5e). However, I shall not attempt to explicate further constraints. The main purpose of the present paper is to explore constraint interaction and meta-constraints, and the constraints advanced so far constitute a sufficient basis for a discussion of these issues, to which we turn in the following section.

\section{Constraint Interaction and Meta-Constraints}

The ranking arguments from section 2 are summarized in (14):
a. Female $\rightarrow$ F (7b) $>>$ Animate $\rightarrow$ M (10)
(cf. ledi $i_{\mathrm{F}}$ 'lady')
b. Male $\rightarrow \mathrm{M}(7 \mathrm{a}) \quad>\operatorname{Decl} 2 \rightarrow \mathrm{F}(5 \mathrm{a})$
(cf. djadja $a_{\mathrm{M}}$ 'uncle')
c. Female $\rightarrow \mathrm{F}(7 \mathrm{~b}) \quad>\operatorname{Decl} 6 \rightarrow \mathrm{N}(5 \mathrm{e})$
(cf. ledi $i_{\mathrm{F}}$ 'lady')
d. Animate $\rightarrow \mathrm{M}(10)>>\operatorname{Decl} 6 \rightarrow \mathrm{N}(5 \mathrm{e})$
(cf. kakadu $u_{\mathrm{M}}$ 'cockatoo')
e. Decl. $2 \rightarrow \mathrm{F} \mathrm{(5a)}>>$ Animate $\rightarrow \mathrm{M}(10)$
(cf. zebra ${ }_{\mathrm{F}}$ 'zebra')
f. Decl. 3 $\rightarrow$ F (5b) $>>$ Animate $\rightarrow$ M (10)
(cf. rys' 'lynx')
g. Decl. $4 \rightarrow \mathrm{N} \mathrm{(5c)}>>$ Animate $\rightarrow \mathrm{M} \mathrm{(10)}$
(cf. stvorinnja $a_{\mathrm{N}}$ 'creature')
h. Decl. $5 \rightarrow \mathrm{N}(5 \mathrm{~d}) \quad>$ Animate $\rightarrow \mathrm{M} \mathrm{(10)}$
(cf. telja $a_{\mathrm{N}}$ 'calf')

It seems to be a growing concern in OT that attested phonological systems are less diverse than predicted by a model where constraints are allowed to interact freely. For instance, de Lacy (2003) addresses this problem by advancing what he calls Prosodic Primacy Fixed Rankings, while Steriade (2001) attempts at eliminating overgeneralization by means of so-called P-maps reflecting perceptibility differences among phonological elements. Against this background, the question arises as to whether the rankings in (14) must be stipulated or whether they follow from independent principles. In the following, we shall consider two strategies for reducing the impact of language specific, free ranking of constraints.

The first strategy involves Panini's Theorem (Prince and Smolensky 1993). ${ }^{4}$ According to this widely accepted principle, constraint A outranks constraint B if A refers to a proper subset of the nouns referred to by constraint $B$. The ranking in (14a) illustrates this. Since nouns denoting females constitute a proper subset of animate nouns, constraint (7b) automatically outranks (10). Furthermore, the default constraint (6) is automatically ranked below all competing constraints, since it refers to nouns in general, while the remaining constraints specify particular subsets of nouns.

Insofar as Panini's Theorem is a universal constraint on constraint ranking, I suggest referring to it as a "meta-constraint". While the examples discussed above testify to the relevance of Panini's Theorem, it seems clear that this meta-

\footnotetext{
${ }^{4}$ The generalization that specific information takes precedence is also known as "Proper Inclusion Precedence" (Koutsoudas et al. 1974), "Elsewhere Condition" (Kiparsky 1982) and "Wilensky's law" (Lakoff 1987).
} 


\section{Tore Nesset}

constraint cannot provide a principled account for all the rankings in (14). However, instead of assuming all the remaining rankings in (14) to result from language specific stipulation, I suggest supplementing Panini's Theorem with a second meta-constraint:

(15) The Core Semantic Override Principle:

In gender assignment, constraints referring to biological sex outrank other constraints.

I refer to (15) as the "Core Semantic Override Principle" because biological sex is of fundamental importance for the category of gender. The Core Semantic Override Principle bears on rankings $(14 b-c)$; it predicts that the sex-based constraints (7a-b) take precedence, a prediction that is borne out by the facts.

There is ample typological evidence in favor of the claim that the Core Semantic Override Principle is part of universal grammar. According to Dahl (2000:101f.), who has investigated a large language sample including all languages discussed in Corbett (1991), sex is the "major criterion" for the assignment of gender in languages with more than one gender for animates. While Dahl's term "major criterion" may seem opaque, it is clear from his discussion that it implies that sex-based gender assignment tends to take precedence. Notice that the provision "tends to" does not indicate that we are dealing with a mere statistical generalization. Rather, the set of cases where sex-based constraints are overridden is limited and well defined. Dahl (2000:103) isolates three cases: ${ }^{5}$

a. Special morphological rules may take precedence for augmentative and diminutive derivations.

b. Special semantic rules may take precedence for nouns denoting young or small animates.

c. Special semantic rules may take precedence for certain kinds of animals.

German diminutives in -chen and -lein are well known examples of (16a). As an illustration of special treatment for nouns denoting young or small animates in (16b), Dahl (2000:103) mentions the assignment of neuter gender to unmarried women in certain Polish dialects (see also Corbett 1991:100). As for (16c), in the Australian language Ngangikurrunggurr nouns denoting animals hunted for meat are relegated to a special gender (Corbett 1991:140, Dahl 2000:105). A detailed discussion of cases of these types is beyond the scope of the present study. Suffice it to say that the typological evidence strongly suggests that sex-based constraints take precedence universally in gender assignment, with the exception of the welldefined cases in (16).

\footnotetext{
${ }^{5}$ In addition, Dahl (2000) mentions the pragmatic effects of "downgrading" and "upgrading" obtained by using the "wrong gender" in certain speech situations. This phenomenon is not included in (16) as it is arguably not part of grammar proper.
} 


\section{Meta-Constraints}

The Core Semantic Override Principle resembles Corbett and Fraser's observation in (17) (see also Corbett 1991:68f.):

(17) "As is universally the case, the formal gender assignment rules [...] are dominated by the semantic gender assignment rules." (Corbett and Fraser 2000a:321)

However, (17) represents a somewhat stronger claim than the Core Semantic Override Principle, since the former pertains to all semantic constraints, while the latter only concerns those semantic constraints that invoke biological sex. Notice that (17) is incompatible with the analysis of Ukrainian presented above. While (17) would predict the animacy constraint in (10) to outrank all morphological constraints, it was shown in section 2 that (10) is crucially dominated by the morphological constraints (5a-d). In order to maintain (17), one would have to replace (10) by (18):

$$
\text { Animate, declension } 6 \rightarrow \mathrm{M}
$$

As this constraint applies to animate nouns in declension 6 only, it does not conflict with (5a-d), which invoke other declensions. Therefore, (18) and (5a-d) need not be ranked with regard to each other.

A statement like (18) is part of Corbett's $(1982,1991)$ seminal analysis of Russian, which was adapted for Ukrainian in Nesset (2003). There are, however, reasons to believe that (10) should be preferred to (18). Restricting (18) to declension 6 is in fact tantamount to saying that the animacy constraint dominates (5e), but not (5a-d). In other words, the ranking statements in (14d-h) have been incorporated in the constraint itself. This is at variance with a fundamental idea in OT where language specific properties of a grammar are expressed in terms of a certain ranking of the relevant constraints. More importantly, however, adopting (18) instead of (10) seems to undermine the falsifiability of (17). If we do away with a counterexample to the hypothesis about ranking in (17) by incorporating the ranking in the problematic constraint itself, we empty the hypothesis of its empirical content. It becomes impossible to falsify (17) if all potential counterexamples can be avoided by smuggling in the ranking information in the constraint itself. In view of this, I suggest adopting the animacy constraint in (10) instead of the one in (18). Accordingly, the Core Semantic Override Principle seems preferable to the statement in (17).

\section{Conclusion}

In this article, I have discussed nine constraints bearing on the assignment of gender to Ukrainian nouns. Summarizing the contribution of the paper, I would like to focus on two aspects of the analysis. First, we have seen that the constraints yield correct predictions provided that a certain ranking is adopted. Secondly, I have suggested that the ranking in part follows from universal 


\section{Tore Nesset}

principles that I have referred to as "meta-constraints". In addition to the widely accepted Panini's Theorem, I have advanced another meta-constraint that I have labeled the "Core Semantic Override Principle".

The present study has several implications for future research. While the proposed analysis suggests that OT is a valuable tool for the investigation of gender assignment, it should be borne in mind that this paper does not offer a complete analysis of the Ukrainian gender system; due to considerations of space some smaller groups of nouns have not been discussed. In particular, it would be interesting to see how OT would handle affective derivatives (augmentatives and diminutives), which are known to involve complexities with regard to gender assignment in Slavic (cf. e.g. Hippisley 1996).

An implication that goes beyond Slavic and the study of gender assignment relates to the growing concern in OT that phonological systems display less variation than predicted by freely ranked constraints. As mentioned in section 3, various attempts have been made to reduce overgeneration by imposing principled restrictions on constraint ranking. The present study lends further support to such a meta-constraint approach, suggesting that meta-constraints are important not only in phonology since gender assignment constraints are subject to universal restrictions on constraint interaction.

\section{References}

Andersen, Henning. 1994. The Ukrainian fourth declension. In M.S. Flier (ed.) Ukrainian Philology and Linguistics (Harvard Ukrainian Studies 18), 154166. Cambridge, MA: Harvard University Press.

Bilodid, I.K. (ed.). 1969. Sučasna ukraïns’ka literaturna mova. Morfolohija. Kiev: Naukova dumka.

Bilodid, I.K. (ed.). 1970-80. Slovnyk ukraïnskoj movy. Kiev: Vydavnictvo naukova dumka.

Carstairs-McCarthy, Andrew. 2000. Inflection classes. In G. Booij, C. Lehmann \& J. Mugdan (eds.) Morphology: An International Handbook on Inflection and Word-Formation, 630-637. Berlin and New York: Walter de Gruyter.

Corbett, Greville G. 1982. Gender in Russian: An account of gender specification and its relationship to declension. Russian Linguistics 6(2): 197-232.

Corbett, Greville G. 1991. Gender. Cambridge: Cambridge University Press.

Corbett, Greville G. and Norman M. Fraser. 2000a. Gender assignment: A typology and a model. In G. Senft (ed.) Systems of Nominal Classification, 293-325. Cambridge: Cambridge University Press.

Corbett, Greville G. and Norman M. Fraser. 2000b. Default genders. In B. Unterbeck and M. Rissanen (eds.) Gender in Grammar and Cognition, 55-97. Berlin and New York: Mouton de Gruyter.

Dahl, Östen. 2000. Animacy and the notion of semantic gender. In B. Unterbeck and M. Rissanen (eds.) Gender in Grammar and Cognition, 99-115. Berlin and New York: Mouton de Gruyter. 


\section{Meta-Constraints}

de Lacy, Paul. 2003. Fixed ranking and the "too many solutions" problem. Paper presented at the CASTL Kick-off Conference, Tromsø, October 2-4, 2003.

Hippisley, Andrew. 1996. Russian expressive derivation: A network morphology account. Slavic and East European Review 74(2): 201-222.

Hockett, Charles F. 1958. A Course in Modern Linguistics. New York: Macmillan.

Hryščenko, Arnol'd P. (ed.). 1997. Sučasna ukrä̈ns'ka literaturna mova. Kiev: Višča škola.

Kiparsky, Paul. 1982. Explanation in Phonology. Dordrecht: Foris.

Koutsoudas, A., G. Sanders, and C. Noll. 1974. The application of phonological rules. Language 50(1): 1-28.

Lakoff, George. 1987. Women, Fire, and Dangerous Things: What Categories Reveal about the Mind. Chicago and London: University of Chicago Press.

Nesset, Tore. 2003. Gender assignment in Ukrainian: Language specific rules and universal principles. Poljarnyj Vestnik 6: 71-85.

Prince, Alan, and Paul Smolensky. 1993. Optimality Theory: Constraint interaction in generative grammar. Report no. RuCCS-TR-2. New Brunswick, NJ: Rutgers University.

Pugh, Stefan M., and Ian Press. 1999. Ukrainian: A Comprehensive Grammar. London and New York: Routledge.

Shevelov, George Y. 1993. Ukrainian. In B. Comrie and G.G. Corbett (eds.) The Slavonic Languages, 947-998. London and New York: Routledge.

Steriade, Donca. 2001. The phonology of perceptibility effects: The P-map and its consequences for constraint organization. Unpublished paper, MIT. (http://web.mit.edu/linguistics/www/steriade.home.html).

Tore Nesset

Dept. of Linguistics/CASTL

University of Tromsø

N-9037 Tromsø

Norway

tore.nesset@hum.uit.no 